and gentle purple hills. Our culture is a composite of freedom seeking people from the old world, shaped to the needs of the new world, and made strong and bold by fortunate environment. From river to river as the summer progressed, traditions of the old world and the new came to life and became community history in hundreds of celebrations as varied as the communities which planned them. ...

The value of these celebrations cannot be stated in dollars and cents. They brought new appreciation of the state to its citizens, and instilled a depth and richness of community and state pride that no other program could have aroused. Iowa bought no glamorous central celebration for passersby to attend and forget, but reached down to the hearts of its people and turned an entire state, from border to border, into one vast celebration that retold the story of its origins and growth. For a single year, history became a part of our daily living. To the public spirited men and women of Iowa, the Committee bequeaths the rare privilege of nurturing and keeping strong and sound the pride in Iowa's past which came to life during the centennial year.

In retrospect, looking back from the year 2046 to the first centennial year 1946, a dreamer may well take just pride in what was done by Iowa people to commemorate the close of their first century of statehood. Iowa was then a glorious state, is now and will continue to befirst free state of the Louisiana purchase, a land devoted to liberty and progress, an empire of abundance.

\title{
EARLY STEAMBOAT EXPLOSION
}

At about 4 o'clock on the morning of Friday last, a flue on one of the boilers of the steamer Polosi collapsed just as she was leaving the wharf at Quincy on her upward trip, mortally wounding N. P. Perring, brother to the captain of the ill-fated Moselle. He died the next afternoon. He has left a wife and six children to mourn his loss. A deck hand by the name of Miller being missing is supposed to have blown overboard and lost. .Fifteen or eighteen others were more or less injured, but none very seriously. We have not heard to whom the blame is to be attached. She was towed down on the next day for repair, and will soon resume her trade.-Bloomington (Muscatine) Herald, October 4, 1844. 
Copyright of Annals of Iowa is the property of State of Iowa, by \& through the State Historical Society of Iowa and its content may not be copied or emailed to multiple sites or posted to a listserv without the copyright holder's express written permission. However, users may print, download, or email articles for individual use. 